\title{
ОСОБЛИВОСТІ ДІЯЛЬНОСТІ НЕУРЯДОВИХ АНАЛІТИЧНИХ ЦЕНТРІВ В УКРАЇНІ
}

\author{
Світлана Полегенько, аспірант кафедри публічної політики та політичної аналітики \\ Украӥна, м. Київ \\ Національна академія державного управління при Президентові України
}

DOI: https://doi.org/10.31435/rsglobal_ws/30082018/6058

\section{ARTICLE INFO}

Received: 18 July 2018

Accepted: 18 August 2018

Published: 30 August 2018

\section{KEYWORDS}

non-governmental think tanks in Ukraine,

institutional capacity of nongovernmental think tanks, information capacity, analytical platforms.

\begin{abstract}
The article provides an overview of the non-governmental analytical environment in Ukraine, represents main stages of the development of non-governmental think tanks and their current state, represents the main features and problems of their functioning, deals with the analysis of information capacity of research centers of Ukraine and their classification, based on the results of recent research conducted within the framework of the Initiative for the Development and Research of Analytical Centers. It describes the position of Ukraine in the annual global ranking of analytical centers 2017 Global Go To Think Tank Index Report's.
\end{abstract}

Citation: Світлана Полегенько. (2018) Osoblyvosti Diialnosti Neuriadovykh Analitychnykh Tsentriv v Ukraini. World Science. 8(36), Vol.1. doi: 10.31435/rsglobal_ws/30082018/6058

Copyright: (C) 2018 Світлана Полегенько. This is an open-access article distributed under the terms of the Creative Commons Attribution License (CC BY). The use, distribution or reproduction in other forums is permitted, provided the original author(s) or licensor are credited and that the original publication in this journal is cited, in accordance with accepted academic practice. No use, distribution or reproduction is permitted which does not comply with these terms.

Вступ. Політичні трансформації, суспільні зміни та досить потужна підтримка зі сторони західних партнерів в наш час створюють унікальні можливості для розширення спектру механізмів участі громадян у процесі демократизації суспільства. Все це стає особливо актуальним з огляду на виклики, які нині стоять перед українською державою.

Задля їх подолання та проведення успішних реформ представники влади як ніколи раніше потребують максимальної консолідації зусиль всіх учасників політико-управлінських процесів, сторонньої допомоги та підтримки від активних представників громадянського суспільства.

Величезного значення набуває інноваційна складова в частині формування i якісного функціонування систем, структур і процедур публічного управління. На фоні чого фіксується попит на послуги незалежних професійних експертів, разом з тим зростає і роль неурядових аналітичних центрів.

Як засвідчили результати національного опитування щодо громадянського залучення, проведеного у червні 2018 року організацією Пакт (Pact) в Україні, зафіксовано зростання рівня довіри українців до громадських організацій з 43 \% до 45\% у порівнянні з показниками станом на вересень 2017 року [1]

На фоні послаблення віри українців в ефективну роботу влади та росту позитивної оцінки роботи представників громадського сектору, спостерігається збільшення відносного впливу громадських організацій.

Все більше людей сподівається, що громадські організації не лише вирішуватимуть вузькогалузеві проблеми, а й дбатимуть про питання державного значення, питання, що лежать в площині публічної політики і спрямовані на задоволення суспільного інтересу, питання для вирішення яких вже недостатньо укомплектованого штату фахівців, що мають відповідну освіту i досвід роботи. Гостро постає питання ролі неурядових аналітичних центрів у сучасних процесах.

В умовах відкритої демократичної системи, де інформація є не лише найважливішим товаром, а й однією із головних складових політичного успіху, неурядові аналітичні центри 
починають виконувати функцію ефективного каналу комунікації між громадськістю, владою та центрами прийняття рішень. Не маючи жодних політичних зобов'язань, вони часто виступають додатковим ресурсом для альтернативних досліджень і отримання незалежної експертної думки, перетворюючись на повноправного актора публічної політики, породжуючи тим самим інтерес науковців до своєї діяльності та ролі в сучасних політико-управлінських процесах.

Результати дослідження. Більшість дослідників під неурядовим аналітичним центром в Україні, розуміють незалежну громадську організацію, що займається аналізом актуальних політичних, соціальних та економічних подій, публікує (поширює) грунтовні, засновані на фактах, аналітичні матеріали, слугує платформою для обміну між експертами та здійснює консультування з питань політики.[2]

Історія функціонування українських неурядових аналітичних центрів тісно пов'язана 3 історичними етапами становлення незалежності України і бере свій початок з 90- років.

Вже в перші роки незалежності України на їі теренах за кошти численних міжнародних фондів, які активно пропонували грантову підтримку недержавному сектору, були створені перші незалежні аналітичні центри серед яких Суспільно-гуманітарний консорціум (СГК) «Генеза», Український центр економічних і політичних досліджень імені Олександра Разумкова, Інститут політики тощо.

Хоча їх ядро склали вихідці з державних аналітичних структур колишнього Радянського Союзу, на думку С. Рябова, ці центри офіційно нікому не підпорядковувалися, самостійно визначали тематику і спрямованість своїх досліджень, добували кошти для їх проведення, i розпоряджалися отриманими результатами як товаром. [3, с. 47].

Хоча згаданий період, що тривав до 2004 року i характеризувався прагненнями незалежних аналітиків заявити про себе на повну силу, досить низький попит на інтелектуальний продукт засвідчили їх непопулярність з боку владних інститутів та фактичну неготовністю значної частини громадян до сприйняття самого факту існування неурядових структур, що мають амбіції участі у виробленні державної політики.

Багато вчених сходяться на думці, що період 32001 по 2004 роки був позначений загостренням стосунків між владою та неурядовими аналітичними центрами. Проти останніх була розгорнута ціла інформаційна кампанія. Яскравим прикладом переслідувань стало створення Верховною Радою України 11 грудня 2003 року тимчасової комісії зі встановлення фактів іноземного втручання у фінансування виборчих кампаній в Україні через недержавні організації, що існують на гранти іноземних держав.

Після подій Помаранчевої революції (2004-2005 рр.) нова влада задекларувала нові підходи до співпраці 3 організаціями громадянського суспільства, які полягали у визнанні високої суспільної значимості діяльності його структур, підтримці розвитку та практичному врахуванні його ініціатив. В цей період фіксується залучення деяких працівників незалежних аналітичних структур до роботи в органах влади. Зокрема, президент Центру Разумкова А. Гриценко обійняв посаду Міністра оборони України, директор Міжнародного центру перспективних досліджень (МЦПД) В. Нанівська очолила Національну академію державного управління тощо.[4].

Та, як засвідчив подальший розвиток подій, сподівання на суттєве покращення умов діяльності та зростання оплаченого попиту держави на їх продукцію, не справдилися. Деякі 3 представників неурядових аналітичних центрів пізніше повернулися 3 органів влади на попередні посади: влада виявилася не готовою сприймати пропозиції неурядових аналітичних центрів і, тим більше, фінансово їх підтримувати.

I лише після подій 2013-2014 років, почали фіксуватися позитивні зрушення. Зокрема досить позитивна динаміка розвитку спостерігається в діяльності вітчизняних неурядових аналітичних центрів, які з організацій, що лише аналізують ситуацію, представляють суспільству власне бачення, поступово перетворюються на повноправних учасників політико-управлінських процесів, що здатні запропонувати альтернативні сценарії вирішення актуальних проблем.

Актуалізується питання інтелектуального посилення, наукового і ідейного обгрунтування, а часто - виявлення і формулювання інтересів тих чи інших соціально-політичних груп через участь неурядових аналітичних центрів у процесі вироблення публічної політики.

На разі є всі умови для їх участі в процесі вироблення й впровадження політик. Якщо раніше мова йшла лише про громадський контроль - тобто про відсторонену роль аналітиків як спостерігачів, без можливості безпосередньо впливати на політику, то тепер аналітичні центри бачать свою роль як безпосереднього учасника процесу публічної політики на всіх іiі трьох етапах: вироблення, впровадження та контроль. 
Як свідчать дані сайту Ініціативи з розвитку та дослідження аналітичних центрів Think Twice UA, станом на початок 2018 року в Україні налічувалося близько 150 незалежних аналітичних центрів, що є осередками дослідження публічної політики. [5] В основному це організації, що спеціалізуються на вузьких галузях політичної, економічної або правової експертизи або займаються проектами адвокації.

За даними дослідження, проведеного в рамках проекту «Зміцнення українських аналітичних центрів: розвиток інституційної спроможності та покращення співпраці 3 партнерами в Свропейському Союзі» станом на кінець 2016 року переважна більшість неурядових аналітичних центрів в Україні була зосереджена в Києві.

До трійки регіонів-лідерів за кількістю їх функціонування входили Київська, Львівська та Одеська області. Разом з тим, в деяких областях взагалі не зафіксовано їх присутності. Серед них Полтавська, Запорізька, Закарпатська, Івано-Франківська області [6].

Таким чином, можемо говорити про те, що в Україні в активній фазі перебуває процес формування і інституційного укріплення незалежного аналітичного середовища, що поступово охоплює всю територію держави і більшість сфер суспільного життя.

В такій ситуації інформаційна спроможність аналітичних центрів, їх здатність поширювати власні бачення та напрацювання серед масової аудиторії часто $€$ індикатором їх впливовості.

Люди схильні більше довіряти тим джерелам, з яких вони неодноразово отримували достовірну інформацію. І обгрунтування того чи іншого рішення стейколдером публічної політики звучить куди переконливіше для пересічного громадянина 3 посиланням на відомий аналітичний осередок, ніж посилання на мало відому інституцію. «Бренд» чи «ім'я» в аналітиці - теж має значення. А популярність і впливіть неурядового аналітичного центру часто взаємопов'язані явища.

Тож не випадково організацією Think Twice було започатковано практику аналізу інформаційної потужності дослідницьких осередків України. Складовою частиною даного рейтингу, що базувався на таких компонентах як згадування у ЗМI, посилання в наукових статтях, відвідуваність сайту, число читачів у соціальних мережах став блок «Інформаційна потужність недержавних аналітичних центрів».

За результатами дослідження, оприлюдненого у 2017 році ТОП-5 недержавних аналітичних центрів за своєю інформаційною потужністю в Україні склали:

- Український центр економічних та політичних досліджень ім. О. Разумкова;

- нститут економічних досліджень та політичних консультацій;

- CASE Україна;

- Фонд «Демократичні Ініціативи» імені Ілька Кучеріва;

- Міжнародний центр перспективних досліджень. [7]

А вже в 2018 році, перша п’ятірка даного рейтингу мала такий вигляд: Український центр економічних та політичних досліджень ім. О. Разумкова зберіг позицію лідера, що не скажеш про інших представників ТОП-5 2017 року: Vox Ukraine - посів 2-ге місце, з четвертої на третю позицію піднявся Фонд «Демократичні Ініціативи» імені Ілька Кучеріва, а Міжнародний центр перспективних досліджень та Інститут економічних досліджень та політичних консультацій посіли відповідно 4-ту та п'яту сходинки рейтингу [8].

На основі наведених даних можемо констатувати той факт, що характерною ознакою ринку незалежної аналітики в Україні $є$ тенденція до появи нових гравців на ньому та укріплення позицій уже відомих та авторитетних.

Зміна лідерів першої п'ятірки представленого рейтингу, свідчить про присутність конкуренції на даному ринку. А її запорукою і гарантією вигідного самопозиціювання служить якісний аналітичний продукт та вдале його просування.

Разом зі збільшенням кількості неурядових аналітичних центрів та активізацією їх діяльності в Україні постає питання їх класифікації.

Як фіксують останні дослідження в залежності від функціонального призначення можна ідентифікувати принаймні три типи неурядових аналітичних центрів поширених в Україні.

Серед них:

- організації, що позиціонують себе як суто аналітичні центри, наприклад CEDOS (раніше Центр дослідження суспільства), Міжнародний центр перспективних досліджень тощо.;

- гібридні неурядові аналітичні центри - організації, що поєднують аналітичну діяльність 3 адвокаційною, ресурсною чи навчальною. Наприклад Фонд «Демократичні Ініціативи» імені Ілька Кучеріва, Центр досліджень енергетики, Центр протидії корупції тощо 
- інституції, що слугують платформою для об’єднання інших організацій, ідей, ресурсів . Серед яких LEAD office, Vox Ukraine, «Майдан Закордонних Справ» та інші [6]

Яскравим прикладом функціонування таких платформ $є$ наприклад Реанімаційний Пакет Реформ (РПР).- найбільша коаліція провідних громадських організацій та експертів України, координаційний центр для 83 неурядових організацій та 22 експертних груп, котрі розробляють, просувають і контролюють реалізацію реформ.

Важливим аспектом функціонування РПР $є$ те, його експерти не тільки долучаються до підготовки та розробки законопроектів у найважливіших напрямках державотворчих змін, але й контролюють їх реалізацію.

Позитивним моментом у функціонуванні даного формату співпраці є те, що кількість учасників платформи та список їх напрацювань постійно зростають [9].

Організації-учасники коаліції та експерти вже можуть похвалитися чималим досягненнями. Зокрема: Центр протидії корупції активно сприяв створенню незалежної системи органів розслідування високопосадової корупції Національного антикорупційного бюро та Спеціалізованої антикорупційної прокуратури.

Інститут громадянського суспільства, Український незалежний центр політичних досліджень забезпечили розробку законодавчої бази та супровід об'єднання територіальних громад, з метою суттєвого розширення їх фінансових та управлінських можливостей.

Ще однією особливістю становлення незалежного аналітичного середовища в Україні $\epsilon$ зростання інтересу до дослідження ролі та місця неурядових аналітичних центрів у вироблені публічної політики в Україні, їх співпраці з органами публічної влади.

Так, в листопаді 2014 року Міжнародним фондом «Відродження» була запущена Ініціатива 3 розвитку аналітичних центрів в Україні, в рамках якої щорічно проходять конференції та публікуються аналітичні доповіді. Метою даної ініціативи є покращення якості та практик прийняття рішень органами влади через підвищення ролі та рівня довіри до аналітичних центрів, зміна їх ролі у процесі вироблення публічної політики через зміцнення їхнього інституційного потенціалу, створення кращих практик їх діяльності, координація фінансових та інформаційних ресурсів донорів, які підтримують діяльність аналітичних центрів в Україні.[10]. Започатковано роботу Ініціативи з розвитку та дослідження аналітичних центрів [11].

Типовими для України стали щорічні конференції представників аналітичних центрів, що вже п'ятий рік поспіль проходять в Україні і в ході яких порушуються найактуальніші питання їх розвитку.

Так, у 2015 році темою конференції була роль аналітичних центрів у ключових реформах в Україні, у 2016 - розбудова аналітичної спільноти для реформ та змін, у 2017 - ключові тенденції і виклики публічної політики в Україні та роль аналітики в суспільних трансформаціях.

Важливим моментом функціонування неурядових аналітичних центрів в Україні $\epsilon$ i ïx співпраця з закордонними партнерами та позиціонування власних напрацювань за межами України.

Як засвідчили дані щорічного світового рейтингу аналітичних центрів «2017 Global Go To Think Tank Index Report» вісім українських аналітичних центрів потрапили до переліку найкращих центрів Європи: Центр Разумкова (4 місце), Міжнародний Центр Перспективних Досліджень (34 місце), Київський Національний економічний університет імені Вадима Гетьмана (36 місце), Фонд "Демократичні Ініціативи" (48 місце), Дніпровський центр соціальних досліджень (49 місце), Інститут світової політики (63 місце), Інститут економічних досліджень та політичних консультацій (86 місце), Міжнародний центр перспективних досліджень (89 місце).

До номінації провідних аналітичних центрів в галузі міжнародної економічної політики потрапили Центр Разумкова (42 місце) та Інститут економічних досліджень та політичних консультацій (69 місце).

Фонд "Демократичні ініціативи імені Ілька Кучеріва"(44 місце) представив Україну в номінації провідних аналітичних центрів в галузі прозорості та якісного державного управління.

Центр Разумкова, зайнявши 29 позицію, потрапив також до списку найкращих аналітичних центрів світу (без урахування США). Цей же центр представив Україну на 43 місці серед найкращих аналітичних центрів світу (з урахуванням США).[12]

3 метою спрощення для українських експертів доступу до європейської влади і європейського ринку аналітики навесні 2014 року в Брюсселі розпочав свою роботу контактний офіс українських аналітичних центрів (Ukrainian Think-Tanks Liaison Office in Brussels). Серед його основних функцій варто відмітити інформаційну, покликану сприяти поширенню візії на події в Україні очима українських експертів. [13] 
Та, незважаючи на досить позитивну динаміку розвитку незалежного аналітичного середовища в Україні, серед основних викликів з якими стикаються вітчизняні неурядові аналітичні центри у 2017 році поруч з залежністю від донорських організацій, браком кадрів та слабкою співпрацею 3 органами публічної влади, заступник генерального директора 3 аналітичної роботі Центру Разумкова Юрій Якименко назвав і обмеженість фінансування.[14]

Так, за даними ГО «Інститут аналітики та адвокації» у 2016-2017 роках на проведення наукових досліджень 3 державного бюджету виділено 5,3 млрд грн та 5,9 млрд грн відповідно. Разом $з$ тим, для України залишається актуальним питання монополізації ресурсів державним сектором. Держава, зазвичай, замовляє дослідження середня вартість яких коливається від 690 тис. грн до 720 тис. грн у своїх же державних установах напряму, без конкурсу.

I лише завдяки запровадженню практики закупівель наукових досліджень через систему «ProZorro» у 2017 році, неурядові аналітичні організації отримали можливість позмагатися на торгах із установами державної власності. За результатами участі у публічних закупівлях, неурядовий сектор отримав замовлень досліджень на понад 1,8 млн. грн., що є втричі більше, ніж у 2016 році. [15]

Сам же існуючий механізм фінансування наукових досліджень на конкурсній основі в Україні відпрацьований недостатньо. І неурядові аналітичні центри змушені шукати кошти на власне існування з інших джерел, часто користуючись грантовими програмами міжнародних організацій.

Висновки. Таким чином, можемо говорити про інтенсифікацію процесу формування незалежного аналітичного середовища в Україні та актуалізацію питання ролі неурядових аналітичних центрів. Як засвідчили результати дослідження, неурядові аналітичні центри в Україні перебувають в активній фазі своєї інституалізації, укріплення в якості повноправного актора публічної політики. Незважаючи на численні проблеми 3 якими вони стикаються в процесі своєї діяльності, фіксується тенденція щодо їх трансформації з організацій, що лише аналізували ситуацію, представляли своє бачення стану справ, критикували дії влади, на інституції, які самі пропонують рішення, спрямовані на задоволення суспільного інтересу. Все частіше вони виступають посередниками між владою, бізнесом та громадянами, лобіюють громадські пріоритети та інтереси шляхом гнучкого реагування на запити політичних діячів, прагнучи в такий спосіб безпосередньо впливати на їх рішення. За таких умов гостро постає питання формування унікального та ефективного механізму їх повноцінної участі в сучасних політико-управлінських процесах.

\section{ЛІТЕРАТУРА}

1. Фонд «Демократичні ініціативи» ім. Ілька Кучеріва. Незадоволення українців роботою чинного уряду зростає, натомість збільшується довіра до громадських активістів [Електронний ресурс]/ Фонд «Демократичні ініціативи» ім. Ілька Кучеріва. - 2018. - Режим доступу до ресурсу: https://dif.org.ua/article/nezadovolennya-ukraintsiv-robotoyu-chinnogo-uryadu-zrostae-natomistzbilshuetsya-dovira-do-gromadskikh-aktivistiv.

2. Мельник Л. Аналітичні центри в Україні та Німеччині: головні розбіжності та перспективи співпраці [Електронний ресурс] / Л. Мельник, М. Паталонг, О. Сидорчук // Фонд «Демократичні ініціативи» ім. Ілька Кучеріва - 2016. - Режим доступу до ресурсу: https://dif.org.ua/uploads/pdf/854168914585d2fd4a3c0f5.81720744.pdf.

3. Рябов С. Політична наука в Україні ХХІ ст.: стан та перспективи розвитку: дослідження / С. Рябов. К.: Навч.-метод. центр «Консорціум із удосконалення менеджмент-освіти в Укра- їні», 2005. - 103 с.

4. Лучик А. Аналітичні центри в умовах демократичної трансформації України] / А. Лучик // Держава і право: зб. наук. праць. Сер.: Юридичні і політичні науки. - К.: Ін-т держави і права ім. В.М. Корецького НАН України, 2013. - Вип. 61. - С. 514-520

5. Українські аналітичні центри [Електронний ресурс]// Think twice UA - Ініціатива з розвитку та дослідження аналітичних центрів. - 2018. - Режим доступу до ресурсу: http://thinktwiceua.org/uk/think-tanks/ukraine/.

6. Ландшафт українських неурядових, державних, університетських аналітичних центрів [Електронний ресурс] // Think twice UA - Ініціатива з розвитку та дослідження аналітичних центрів. - 2016. - Режим доступу до ресурсу: http://thinktwiceua.org/uk/ttua-content/landshaft-ukrayinskyhneuryadovyh-derzhavnyh-universytetskyh-analitychnyh-tsentriv/.

7. Інформаційна потужність аналітичних центрів 2016 [Електронний ресурс] // Think twice UA Ініціатива з розвитку та дослідження аналітичних центрів. - 2017. - Режим доступу до ресурсу: http://thinktwiceua.org/uk/spetsproekty/informatsijna-potuzhnist-analitychnyh-tsentriv/.

8. Інформаційна потужність аналітичних центрів України за 2017 рік [Електронний ресурс] // Think twice UA - Ініціатива з розвитку та дослідження аналітичних центрів. - 2018. - Режим доступу до 
pecypcy: http://thinktwiceua.org/uk/spetsproekty/informatsijna-potuzhnist-analitychnyh-tsentriv-ukrayinyza-2017-rik/.

9. Здобутки членів коаліції РПР [Електронний ресурс] // Реанімаційний пакет реформ. - 2018. - Режим доступу до ресурсу: https://rpr.org.ua/zdobutky/.

10. Ініціативу 3 розвитку аналітичних центрів [Електронний ресурс] // Міжнародний фонд «Відродження». - 2017. - Режим доступу до pecypcy: http://www.irf.ua/programs/support-think/.

11. Про нас [Електронний ресурс]// Think twice UA - Ініціатива з розвитку та дослідження аналітичних центрів.. - 2017. - Режим доступу до ресурсу: http://thinktwiceua.org/uk/pro-nas/.

12. McGann J. 2017 Global Go To Think Tank Index [Електронний ресурс] / James G. McGann // Think Tanks \& Civil Societies Program The Lauder Institute The University of Pennsylvania. - 2018. - Режим доступу до ресурсу: http://razumkov.org.ua/uploads/article/2018_GGTTI_PrereleaseGotoReport_1.28.18.pdf.

13. Сидоренко С. «Ми об'єднуємо організації, але не змушуємо їх думати однаково» [Електронний ресурс] / С. Сидоренко // Свропейська правда- Режим доступу: http://www.eurointegration.com.ua/interview/2014/06/25/7023641/

14. Експерт Центру Разумкова назвав основні проблеми аналітичних центрів у 2017 році [Електронний peсурс] // Інформаційне агентство Інтерфакс-Україна. - 2018. - Режим доступу до ресурсу: https://ua.interfax.com.ua/news/political/481027.html.

15. Державне фінансування досліджень для недержавних аналітичних центрів [Електронний ресурс] / [О. В. Дмитренко, Ю. Ю. Романов, П. В. Колганова та ін.] // ГО «Інститут аналітики та адвокації».2018. - Режим доступу до ресурсу: http://iaaukraine.org/wp-content/uploads/2018/06/Analitychnyjzvit_Derzhavne-finansuvannya-doslidzhen.pdf. 